\title{
THE EXPANSION OF LJUBLJANA ONTO THE LJUBLJANSKO BARJE MOOR ŠIRITEV LJUBLJANE NA LJUBLJANSKO BARJE
}

Primož Gašperič

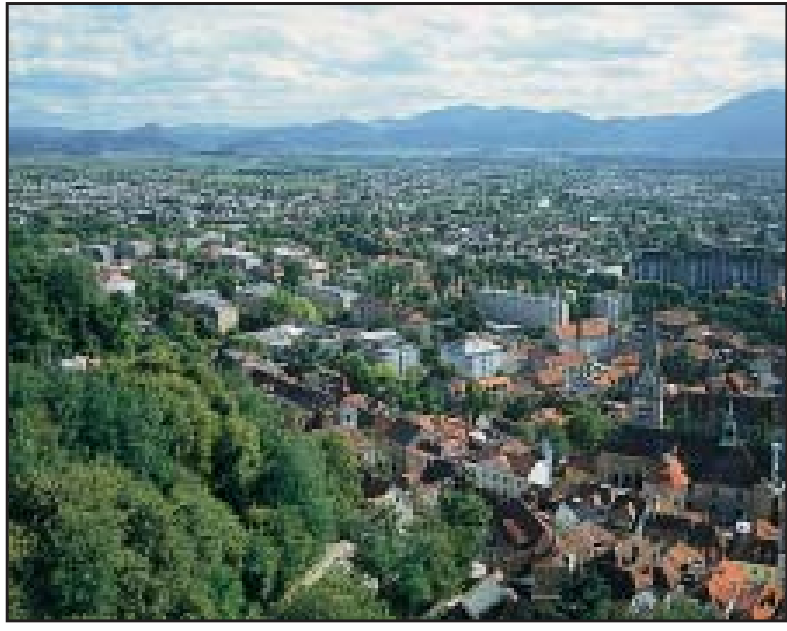

The city of Ljubljana is increasingly spreading also to the moor (photography Jurij Senegačnik).

Ljubljana se vse bolj širi tudi na barje (fotografija Jurij Senegačnik).

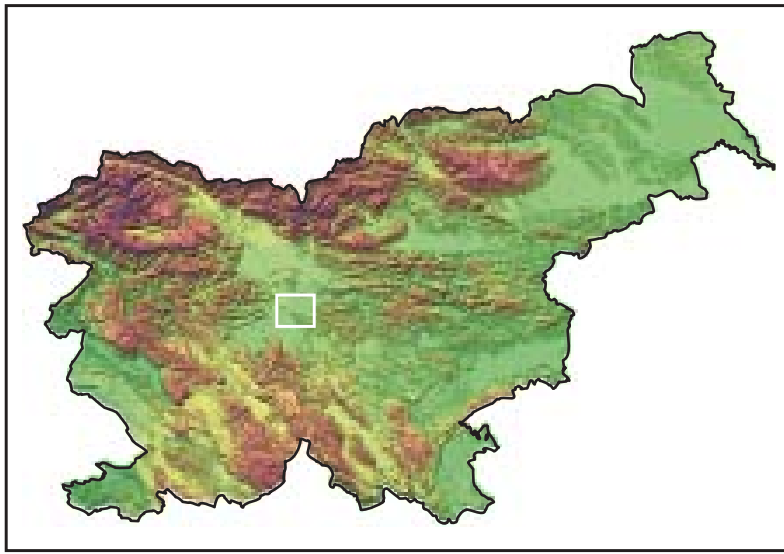




\section{The expansion of Ljubljana onto the Ljubljansko barje moor \\ UDC: 911.375(497.4 Ljubljana) \\ COBISS: 1.01}

ABSTRACT: Ljubljana began its southward expansion south relatively late because the characteristics of the Ljubljansko Barje moor had a hindering effect on the expanding process of the city. However, with the gradual development of industry and commerce and the growing number of immigrants, the process of urbanization gradually started to spread into this area. The beginnings of the expansion began in the 1960's and intensified from the 1970's on. Along with organized construction, unregulated illegal construction was very widespread and settled numerous areas that were later rounded out and individual parts of previously still unurbanized areas. Supervision over these construction sites was poor and allowed uncontrolled settling, which in places dictated the directions of further urban development.

Due to its proximity of the center of the city, the area considered in this study became increasingly important. The number of activities increased greatly, shopping centers and the infrastructure network developed, and the comprehensive solution of communal network is still in the process of formation.

Although this study covers only a part of the entire city, numerous smaller areas within it developed that have their individual characteristics and differ greatly, which is reflected in the pattern of settling, the development of the areas, and the structure of the population. For this reason, the area studied is extremely heterogeneous and, as such, a challenge for further research.

KEY WORDS: Ljubljana, city expansion, urban sprawl, Ljubljansko Barje moor, urbanization, settling.

\section{Širitev Ljubljane na Ljubljansko barje}

UDK: 911.375(497.4 Ljubljana)

COBISS: 1.01

IZVLEČEK: Ljubljana se je razmeroma pozno začela širiti proti jugu, saj je barje z vsemi svojimi lastnostmi zaviralno vplivalo na širitveni proces mesta. Vendar pa se je s postopnim razvojem dejavnosti in vse večjim številom priseljencev proces urbanizacije začel postopno širiti tudi na to območje. Začetki širitve se začnejo v šestdesetih letih dvajsetega stoletja, najbolj intenzivno pa od sedemdesetih let naprej. Poleg organizirane gradnje je bila zelo močno razširjena stihijska gradnja, s katero so bila poseljena številna kasneje zaokrožena območja in posamezni deli do tedaj še neurbaniziranih območij. Nadzor nad temi gradnjami je bil slab in je omogočal nenadzorovano poselitev, ki je ponekod začrtala smeri nadaljnjega urbanega razvoja.

Zaradi bližine središča mesta je obravnavano območje dobivalo vse večji pomen. Močno se je povečalo število dejavnosti, razvila so se trgovska središča in infrastrukturno omrežje, v procesu nastajanja pa je še celostna rešitev komunalnega omrežja.

Kljub temu da gre le za del celotnega mesta, so se razvila številna manjša območja, ki imajo posamezne svojske značilnosti, med seboj pa se močno razlikujejo. To se kaže pri načinu poselitve, razvitosti območja in strukturi prebivalstva. Zato je obravnavano območje izrazito heterogeno in kot takšno izziv za nadaljnje raziskave.

KLJUČNE BESEDE: Ljubljana, širitev mesta, Ljubljansko barje, urbanizacija, poselitev.

\section{ADDRESS - NASLOV:}

Primož Gašperič, B. Sc.

Anton Melik Geographical institute

Scientific Research Centre of the Slovenian Academy of Sciences ans Arts

Gosposka ulica 13

SI - 1000 Ljubljana

Slovenia

Phone - telefon: +386 (1) 2002721

Fax - faks: +386 (1) 2002734

E-mail - e.pošta: primoz.gasperic@zrc-sazu.si 


\section{Contents}

1 Introduction $\quad 10$

$2 \quad$ Outline of the studied area 11

3 Risk of floods and earthquakes 12

4 Expansion of the city southward 14

5 Conclusion 24

6 Bibliography 25

\section{Vsebina}

1 Uvod 26

2 Oris obravnavanega območja 26

3 Možnosti poplav in potresov 28

$4 \quad$ Širitev mesta proti jugu $\quad 29$

$5 \quad$ Sklep 33

$6 \quad$ Literatura 33 


\section{Introduction}

This article presents the expansion of the City of Ljubljana and the gradual spread of its southern border onto the Ljubljansko Barje moor. My starting point was the fact that Ljubljana started to expand southward onto the moor very late, but in spite of this, the peak of the greatest urbanization has already been achieved. I assumed that although the process of settling is not yet finished, all the major directions have been established and the major part of the area has already been settled. The studied area is the southernmost part of the city of Ljubljana. Until recently, these suburbs were still expanding in this area, which in the last few decades has merged with the city as a somewhat new, additional, and unique part of the entire city.

The territory covered is a selected area that I originally limited on the basis of my sociogeographical conceptions. It seemed logical to include the entire southern part of the city, which would allow me to illustrate the entire urbanization process of the expansion onto the moor. To define the southern margin of the studied area, I chose the southern Ljubljana ring road, which is a kind of physical boundary of an originally uniform territory. Later, it proved that the area is divided into numerous unique urban parts, which in spite of this division together form the entire area now referred to as »the Barje part of Ljubljana (»barjanska Ljubljana«) whose settling boundary is the southern ring road.

The studied area is situated in a rough triangle, extending in the west to Tržaška cesta (street) paralleling the railroad, in the east to Dolenjska cesta and the railroad, and in the south to the aforementioned southern Ljubljana ring road. The remnant of the ancient wall of Roman Emona can be considered the northern boundary.

The area of expansion encompasses about ten square kilometers and covers only a small section (about 1/20) of the entire Ljubljansko Barje moor. Until the second half of the 1990's, this area was administratively divided into eleven local communities: Barje, Galjevica, Kolezija, Milan Česnik, Stane Sever, Zeleni Log, Murgle, Peruzzi, Rakova Jelša, Trnovo, and Rudnik. A few years ago, the local communities were abolished and the area was newly divided into the districts (also called »quarter communities «) of Rudnik, Trnovo, and Vič. These administrative divisions do not coincide exactly with the studied area, but the aberrations are minor.

The area can be defined as marginal, transitional, and intertwining. Due to its position and status relative to the city, the studied area is marginal. It consists of the southern part of the city that was urbanized only gradually and was only incorporated into the city in the last few decades. »Transitional « is a very apt definition. In the northern part closest to the center of the city, it has the true appearance of a city and all of its features. Here there are large built-up areas, residential areas, service activities, a little still cultivated land, and recreation areas. Toward the south and southeast, the city character fades, the density of built-up areas in particular is lower, and toward the outskirts of the city there is an increasing proportion of green areas, which due to the abandonment of farming and the poor quality of the soil have no special importance and as large meadows form the increasingly characteristic appearance of the Ljubljansko Barje moor. In this direction, the density of the settling decreases considerably, although only south of the ring road does it drop very sharply or almost disappears (with the exception of areas around the larger roads such as Cesta dveh cesarjev and Ižanska cesta). Although the ring road was built relatively late, relative to the expansion of the city it represents a border between a relatively densely settled area and the very sparsely settled moorland.

Because of the great differences in land use, the pattern of settling, and the distribution of various types of activities, we can claim that the studied area is a kind of conglomerate of urban, suburban, and even village qualities all intertwined within a relatively small area. Along with those already mentioned, a further reason for this intertwinement is also found in the chronological development of the area. During the gradual changes that occurred from the middle of the $19^{\text {th }}$ century to the middle of the $20^{\text {th }}$ century and the very intensive changes in the last few decades, an urbanized part of the city containing isolated undeveloped »islands « with characteristic meadows developed from the distinctly suburban and agrarian areas. 


\section{Outline of the studied area}

The studied area is a constituent part of the Urban Municipality of Ljubljana and from the geographical point of view forms the southern part of the city. However, this has not always been the case. In the past, this area was originally completely outside the city area. In the period of Roman rule, the southernmost part of the city of Emona reached only to Mirje, the northernmost part of the studied area. This is still visible today because the southern section of Emona's wall and its south gate have been preserved and partly restored. For centuries after the collapse of the Roman Empire, this area remained almost unsettled because it was not protected from natural disasters such as floods and because it was not very attractive for settling due to the poor quality of the soil. The first more radical changes to the environment created conditions for the gradual settling of this part of the Ljubljansko Barje moor. In the second half of the $18^{\text {th }}$ century, efforts began to drain the moor, and with this came more serious encroachments into this space. Between 1772 and 1780, the Gruberjev prekop channel was excavated and contributed much to the greater outflow of water from the moor, thus decreasing the risk of floods. In addition, numerous ditches were progressively dug along the roads and between plots of land.

In time, numerous settlements developed that except for those closest to Ljubljana never had much in common with the city. They formed independent settlement units that were not a part of the city, although economic links existed since people in the moor settlements near Ljubljana produced vegetables and sold them in the city. Water routes, especially the Ljubljanica River, served to connect the more remote places with the city since they were used to transport food and building materials such as stone from Podpeč, wood, etc.

In the second half of the $19^{\text {th }}$ century and even more in the $20^{\text {th }}$ century, the pattern of land use and the density of settling changed substantially. On the one hand, the successful drainage of the land and the construction of individual roads connecting the more remote places with Ljubljana resulted in a higher density of population in these settlements, while on the other, Ljubljana expanded toward the moor, which compared with other directions of expansion was among the last to appear. The reason for the late urbanization of the southern part of today's city can be found in the structure of the moorland, which was neither fertile nor suitable for any type of construction.

Until the beginning of the $20^{\text {th }}$ century, the southern edge of Ljubljana was divided into suburbs. In the southern part of the city directly below the castle was Karlovško predmestje (»suburb «), and on the other side of the Ljubljanica River, Krakovsko predmestje and Trnovsko predmestje. The city limits of Ljubljana stretched south to the Mali graben stream and the road to Murgle where still today two buildings that formerly served as city tollhouses are preserved. Along Tržaška cesta, there were the two smaller old agrarian settlements of Glince and Vič.

In the studied area, Krakovo and Trnovo hold a central position relative to the geography and from the viewpoint of the changeability of the landscape, Krakovo as the northernmost part of the studied area and Trnovo as a kind of southern extension of the city onto the moor. Trnovo is also interesting because of its relatively small area on which in the past but especially today, elements of a real city were visible on the one hand and on the other, typical moor and agrarian remnants that testify to the once quite different character of the area.

The network of roads and railroad lines was adapted to natural factors. An exception is certainly Ižanska cesta (Ig Road), built across the moor in 1826, which was an important connection between Ljubljana and Ig and thus between southeastern part of the Ljubljansko Barje moor and the city.

The only longer street situated almost entirely in the studied area, Cesta dveh cesarjev (»Street of Two Emperors «) has an interesting history of origin. It was built in 1821 when Ljubljana hosted the Congress of the Holy Alliance. The Austrian Emperor Carl drove with the Russian emperor down this road, which was constructed for this very purpose, to show him the latest achievements and ideas, according to which the moor was to become a granary. 
Dolenjska cesta (»Dolenjska Street«) and Tržaška cesta (»Trieste Street«), along which run railroad lines and which simultaneously limit the studied area, are the two main streets that are a kind of »social border « between the moor and non-moor areas. These roads played a connecting role early in their history, and the destinations they connected Ljubljana with are clear from their names. At the same time, they have a kind of cause-effect relationship with Ljubljana since they represent the main traffic arteries of the city leading toward the southeast and west.

The most important road acquisition for the entire city was the southern part of the Ljubljana ring road, which opened at the end of the 1980's. Its opening represented the start of the construction of the entire road ring around the increasingly populous capital city. It is also the southern border of the area encompassed by this study.

Although the rivers are no longer used for the transport of goods and people, it is necessary to mention the Ljubljanica River. As early as Roman times, its riverbed was regulated and it was straightened so it was possible to navigate unhindered. Right up to the $19^{\text {th }}$ century, it remained an important shipping route because it was one of the longest and most important navigable routes on Slovene territory. With the development of the road and railroad infrastructure, its importance inevitably dwindled, and today it is used only for sport and occasional tourist activities.

\section{Risk of floods and earthquakes}

One of the major characteristics and a major problem of the Ljubljansko Barje moor is flooding. Frequent floods occur over its central parts, during which water covers about $15 \%$ of the entire surface. During exceptionally large floods, a good half of the Ljubljansko Barje moor can be under water. From Vrhnika toward Ljubljana, the flood area narrows. Numerous streams, notably the Gradašcica, deposited large amounts of alluvium on this area. These deposits were carried by the river from the northern margins of the moor, creating a higher area that can no longer be covered by ordinary floodwaters. Due to artificial and natural obstacles, the flood area is divided into several smaller parts. The border of frequent floods along the Ljubljanica River has moved back from the river because of its raised banks, in places as much as 500 meters. During exceptional floods, the water covers large areas of the southern parts of the moor and on the left side of the river can reach all the way to Trnovo. Floods on the moor are most frequent in fall and winter, while there are few floods in summer and somewhat more in spring. This distribution indicates that the floods are closely linked to the distribution and quantity of precipitation that falls and that flows away down the streams. (Lovrenčak and Orožen Adamič 1999, 383)

The reasons for the occurrence of floods vary, but among the most important and predominant causes are three fundamental factors:

- non-karstic surface waters, particularly the Gradaščica and Iška rivers, rise rapidly during heavy precipitation, flooding and obstructing the Ljubljanica River to raise its level. When this floodwater recedes, high water from karst springs that was retained in the karst underground starts to flow in. Floods from karst waters reach their climax later than those caused by surface waters. This floodwater subsides later as well because water flows more slowly in the karst underworld.

- The slight incline of the moor surface is also of great importance. The majority of the Ljubljansko Barje moor lies at an altitude between 288 and 289 meters. On such a flat surface with minor elevations and depressions, floodwaters remain long after the water has flowed off the elevations.

- Another reason for the occurrence of floods is the groundwater in alluvial fans on the margins of the moor and in the gravel alluvium between individual streams. Numerous springs occur where the groundwater reaches the impermeable clay on the bottom of the moor (Lovrenčak and Orožen Adamič 1999, 383 and 384).

The belief that floods are a constituent part of the moor and are not a typical natural factor to concern the southern part of the city is very widespread. The frequency of floods in this area is considerably lower because localized regulation work was done on individual streams and numerous ditches for draining water 
were excavated during the past century. However, in the event of a combination of circumstances such as occurred, for example, in 1926 and 1933, it is not possible to prevent the reoccurrence of catastrophic floods. Various experts on hydrographical conditions and the Water Management Institute in Ljubljana believe that to prevent floods reservoirs should be built on individual streams in the studied area, especially on the Gradaščica, that would allow us to control the water levels in the event of major quantities of water, that individual water courses should be regulated, and that more suitable urban planning would improve the outflow into channels.

With the passage of time since the last major floods in the 1920's and 1930's, the awareness and knowledge of the threat from flooding has diminished. The strong urbanization with the influx in recent decades of new immigrants who have no knowledge of the natural processes and conditions on the moor further contributes to this ignorance. In practice, it is reflected in the pattern of settling and in the construction of houses. Many buildings are not sufficiently elevated from the basic ground level, and floods can potentially inundate their ground floors. Along with the obvious types of construction and the statements of individual residents in the area, a survey carried out in 1983 confirmed this hypothesis (Gams and Cunder 1983, 131 and 134). The aim of the survey was to discover what the residents believed or knew about earthquakes and floods in the area surveyed. The area encompassed by the survey almost coincides with the area of this study.

Part of the survey included questions about floods and questions related to them:

- almost $60 \%$ of those questioned had the ground floor of their homes less than 20 centimeters above the immediate surroundings;

- $72 \%$ did not know that catastrophic floods are possible in their area;

- 59\% did not know that the area had previously been flooded, and 13\% had no opinion on the matter;

- $52 \%$ believed there was a possibility that flooding could occur;

- $53 \%$ of the septic tanks of homes had been flooded at some time in the past (25\% did not know the answer to this question).

Along with floods, earthquakes also threaten the studied area. Due to numerous faults and the gradual sinking of the ground, there is a threat of an earthquake stronger than nine degrees on the Mercalli Intensity Scale to the southern part of Ljubljana. A question that arises is whether the moor ground reduces or increases the level of potential earthquake damage. Artificial simulations of earthquakes have indicated that the moor foundation increases the level of earthquake damage, and in this area it can even reach ten degrees on the Mercalli Intensity Scale. These figures are very worrying, but the awareness of the threat from earthquakes is low due to the relative rarity of catastrophic earthquakes and the more than one hundred years that have passed since the last major earthquake struck Ljubljana in 1895. Because there are many illegally constructed houses in this area, we can assume that many buildings were not built according to the standards required for earthquake safety. In all probability, the main reason for such construction is the lack of knowledge of the terrain and the economic status of the population.

Due to earthquake threat in the surveyed area, the second part of the survey questionnaire included questions on this topic:

- $43 \%$ of those questioned were aware of the possibility of earthquakes before construction;

- $65 \%$ stated they would not move to a different place if they had the option to go elsewhere (the probable reason for this is the proximity of the city center);

- 39\% responded that their houses were not earthquake safe;

- $38 \%$ occasionally thought about the possibility of a catastrophic earthquake, $21 \%$ never thought about it.

The assumptions we can make on the basis of the results of the survey can be summarized briefly: the residents of the studied area are not sufficiently informed about or aware of the possibility of natural disasters. Many did not consider the possibility of such disasters during the construction of their homes, and it is therefore difficult to assess the extent of potential damage and casualties. However, many residents expressed their readiness to participate with money and work in the collective renovation of their homes if this would result in safer living conditions. 
In the twenty years since the survey was done, I assume that the awareness of natural disasters has not increased; I would even dare say that it has decreased. The following factors support this assumption:

- the informing of the area's population of the dangers via the media or through other activities and events is negligible;

- many people from other places immigrated to the studied area after 1983, and we can justifiably assume that a large number of them have no knowledge of this problem;

- since neither natural disaster has occurred here in the last twenty years, the knowledge and awareness have further diminished with time.

\section{Expansion of the city southward}

In the 1950's and partly into the 1960's, this area, with the exception of the northernmost parts and individual roadside areas (along Tržaška cesta and Dolenjska cesta), was still very sparsely settled and had a predominantly agrarian character. The gradual expansion of the city, which started in the 1960's, is the consequence of two types of urbanization. With planned urbanization, guidelines for the further settling direction and expanding onto the moor were established. One of the first and most extensive encroachments was the Murgle development, which by the middle of the 1960's had substantially changed the appearance of the city south of Cesta v Mestni Log street. Due to illegal construction, however, unsupervised and dispersed urbanization also began that gradually increased in scope. Rakova Jelša can be pointed out as the most characteristic and later also the densest area of illegally built housing. The originally low number of illegal buildings became increasingly numerous to the point where they became a very powerful factor in the formation of the settlement system in the studied area. The gradual legalization of these buildings in the 1990's legitimized these unplanned settling processes and included them in the further development of the expanding city.

It is difficult to determine which of the two types of urbanization began first, but in any case, while they both had similar reasons for their origin, they have completely different realization in space. The main reasons for the expansion of the built-up area and of the settlement area include the following:

- the proximity to the city center of Ljubljana,

- the low price of land or inherited property,

- weak or unsupervised regulations regarding the construction of residential buildings,

- the possibility of relatively low initial capital expenditure, which allowed the initial construction of makeshift temporary housing,

- the possibility of »communal « settlements: areas that attracted groups of people with the same economic, ethnic, or other characteristics,

- the possibility of arbitrarily chosen building plans, limited only by the nature of the moor ground.

In spite of the varied construction plans and reasons for settling, we can only speak of gradual urbanization, in whose context the very characteristic features of suburbanization are evident. This is another reason the studied area is unique. Even in the 1950's, the already sparse population was moving more toward or into the city, and the density of settling in the more remote parts of the then still suburbs did not increase substantially. We can hypothesize that the urbanization of the studied area reflects the influx of population to this area from other areas, which consequentially led to the expansion of the city. People moved to the Ljubljansko Barje moor for the reasons listed above, and they originally came from more distant places. Within a few decades, the studied area grew to such an extent that settling physically reached the limits of the city of Ljubljana, which had been established under the influence of natural conditions and human activity. The area's southern border is certainly the clearest, being directly defined by the southern Ljubljana ring road. In individual parts, the built-up area reached this limit in the 1970 's, and more distinctly in the 1980's. However, a considerable part of the area still remained undeveloped, mainly in the east of the studied area. From the 1990's on, the part east of the Ljubljanica River became increasingly built-up, and illegally constructed buildings were gradually legalized. It was no longer just people from more distant places who moved into this area; many new residents came from the immediate surroundings of Ljubljana or from the city itself. The latter decided to buy a row house or a single-family 
house because of the lack of living space in the city and/or because of their improved financial status. Since these citizens of Ljubljana moved into this area from the city and this was therefore a »city to city« migration, we cannot call this process »suburbanization. «Along with them, people from more or less distant places around Ljubljana continued coming to the area, further encouraging the process of urbanization.

Gradually, the number of buildings as well as the size of the population in the already built-up areas increased because individual immigrants had lived here for three or four decades and a part of the younger generation still lived with their parents or presumably built their own housing there as well. With the expansion of the urbanized area, increasingly more service activities gradually appeared, mostly related to commerce and various skilled trades. Originally, these activities were intended to satisfy local needs, but in the last decade, particularly in the last few years, very large shopping centers developed, built to satisfy the needs of the entire city area and its wider surroundings. These new commercial facilities will easily satisfy the needs of this increasingly populated area in the future. In this way, the process of urbanization is intensifying and gradually heralding its completion, which, however, is not yet so near since it will take at least a decade to settle the entire area. According to the spatial planning outlined in the Spatial Plan for the Urban Municipality of Ljubljana and several architects, individual smaller areas will not be built up but will instead be included in this urbanized space as multi-functional areas. These are mostly areas intended as recreation areas and areas intended for later planned uses, for example, for the city's light railway public transportation system.

Throughout its history, Ljubljana acquired a central role in the territory of today's Slovenia, the inevitable consequence of which was the gradual expansion of the city. However, its expansion was not even, for which individual physical factors and spatial diversity are the reason. In the east and west, these include Tivoli Park and the Castle Hill, and in the south, the Ljubljansko Barje moor. The Romans were familiar with the characteristics of the moorland and built Emona on the edge of the moor, but a little to the north where the ground was more solid. It is interesting that during so many centuries that followed, the border of the city moved only a few hundred meters southward and only alongside the more important roads did the settling spread onto the moor. In the $19^{\text {th }}$ century and the first half of the $20^{\text {th }}$ century, the rural suburbs did extend to the moor, but we still cannot talk about the expansion of the city toward moor since these were only smaller settlements with characteristic rural functions and types of settlement (Trnovo, Krakovo) and individual islands of settlement that were built to resettle refugees fleeing the fighting in World War I (Galjevica, Sibirija). With river shipping and the brickworks that were active in the southern part of today's Trnovo (Opekarska cesta), settling consolidated but was not a strong enough factor to merge the Trnovo suburb with the city.

The lateness of the expansion of the city onto the moor was not circumstantial but rather the consequence of numerous features and their related problems that are specifically characteristic of moors. The principal reasons having a negative influence on the possibility of settling included the following:

- more demanding and therefore potentially more costly construction on piles or dikes,

- infertile moor soil,

- high water table,

- possibility of floods.

With the gradual rise in the standard of living, the demand from the population for comfortable housing increased and certain elements of the modern living environment (sewage system and infrastructure network, spacious and attractive housing, etc.) became a necessity. In the period following World War II, several new reasons for settling the moor and an increasing demand appeared that countered the reasons for delay, fostered settlement over the following decades, and are still an important factor in the decisions of future possible residents:

- affordable land prices,

- installation of infrastructure network,

- possibility of connection to the sewage system,

- proximity of services,

- the general perception or stereotype image of a specific area. 
Map 1: Expansion of the southern margins of Ljubljana, 1951.
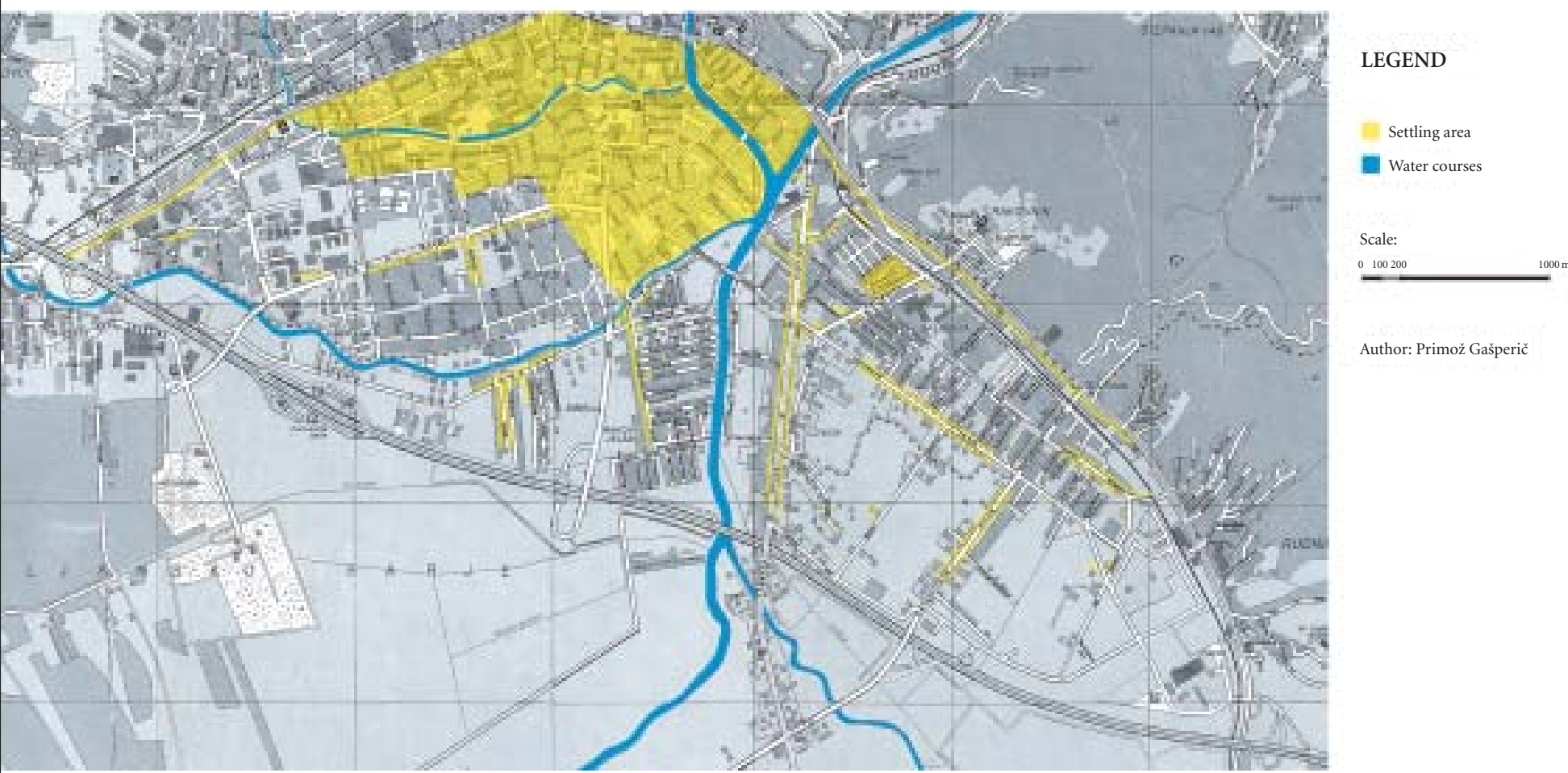

Author: Primož Gašperic 
Map 2: Expansion of the southern margins of Ljubljana, 1964.

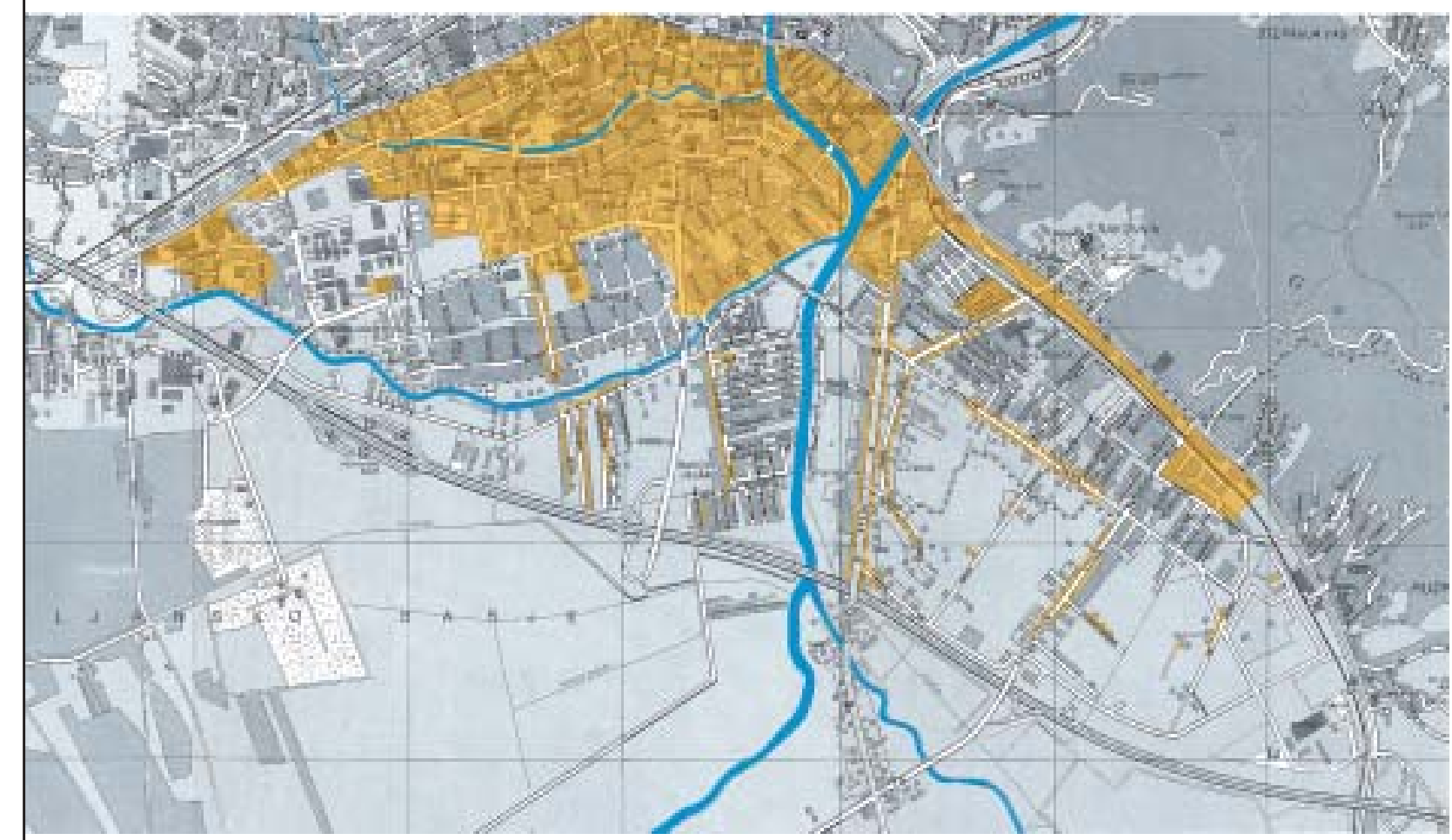

LEGEND

117t Settling area

Water courses

Scale:

.002200

Author: Primož Gašperič 

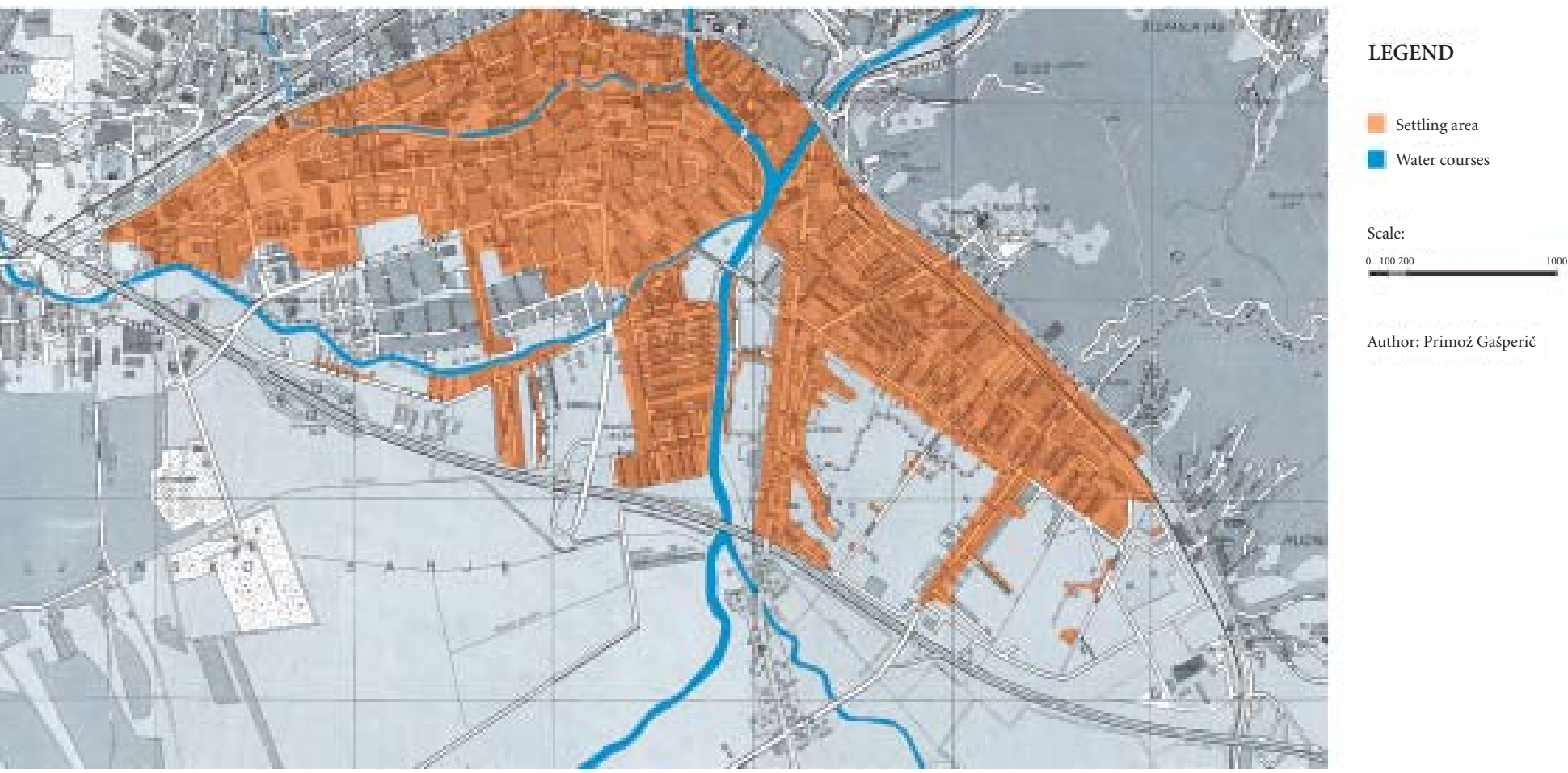

Author: Primož Gašperič 
These factors can be positive or negative depending on the individual locations within the studied area. For example, Rakova Jelša has a more negative reputation relative to the sewage system and stereotype image but land prices are considered better, while the situation is the reverse regarding Murgle.

The rising standard of living and the associated desire for a certain lifestyle are clearly evident in the factors affecting the decision to move or build a home here. Before and at the beginning of the studied period, the negative factors listed above were the reason the area was not settled, and during the 1960's and partly into the 1970's, the characteristic negative factors included the poor installation of the infrastructure and sewage systems, the lack of service activities, and the correspondingly poor reputation of the area. In the 1980's and 1990's and even more in the last few years, circumstances have changed dramatically due to the gradual urbanization of the area. Because of its proximity to the city center, the studied area became a very attractive location for settling and for setting up numerous activities. This led to the development of the infrastructure network and a rise in the quality of housing. The primary factor limiting settling became the cost of land and house construction, which compared with previous decades had increased by more than ten times. As a result, in the most recent period, people with higher incomes are moving into new developments or newly-built single-family houses. In spite of this, the structure of the population remains very heterogeneous since the majority of the area's residents moved here when land and construction were not yet so expensive.

The studied area is a kind of conglomerate of the most diverse classes of people and various types of settlements and activities. Its residents differ distinctly according to their financial status and the places from which they moved. For this reason there are planned areas and developments such as Murgle on one hand and on the other »spontaneously« occurring areas such as Rakova Jelša that appear homogenous at least from the outside in terms of the style of construction and the structure of the population.

This review of the expansion of Ljubljana onto the Ljubljansko Barje moor begins in 1951. This was the period when conditions after World War II gradually returned to normal and the new political orientation appeared and is the last period when the expansion of the city and urbanization had not yet encroached significantly into this area.

The city limits in this period do not match the limits of settling, although only the partly consolidated settling toward the south in Trnovo and partly in Kolezija stand out clearly. The actual city limits ran along the Ljubljanica River from Špica to the mouth of the Gradaščica River and partly along the Gradaščica. Trnovo and Krakovo already formed unique and rounded areas in the prewar period when their residents made a living primarily by producing fresh vegetables to sell in the city and from transporting goods on the Ljubljanica River. Additional development was made possible by small brickworks, but due to the development of the road infrastructure and their inability to compete, the shipping operations and the brickworks went bankrupt. The characteristic vegetable gardens remained the prevailing type of land use in this period. Over the entire period studied, the gardens gradually shrank, but individual plots have survived to the present day.

The start of the expansion of the city onto the moor marks the 1960's. The expansion was not rapid and intensive but was rather gradual and took place in several phases. On the one hand, the construction of planned developments began, while the other, illegal construction began in the studied area that to some extent was already dictating the direction of future settling concentrations.

The 1970's were a period of intensive planned and illegal settling of the studied area and with it, the southward expansion of Ljubljana. Murgle acquired its appearance as a development of single-family houses and had reached the third construction phase although work was not finished. In a very short period, settling expanded in Rakova Jelša to the limits that are still recognized today. South of Dolenjska cesta, the limit of settling moved to Jurčkova cesta with the intensive construction of row housing and single-family houses. Compared with the previous period, this type of construction developed strongly, achieving its most intensive form in the 1970's. The reasons for this, as mentioned earlier, were primarily economic. 
Map 4: Expansion of the southern margins of Ljubljana, 1982.
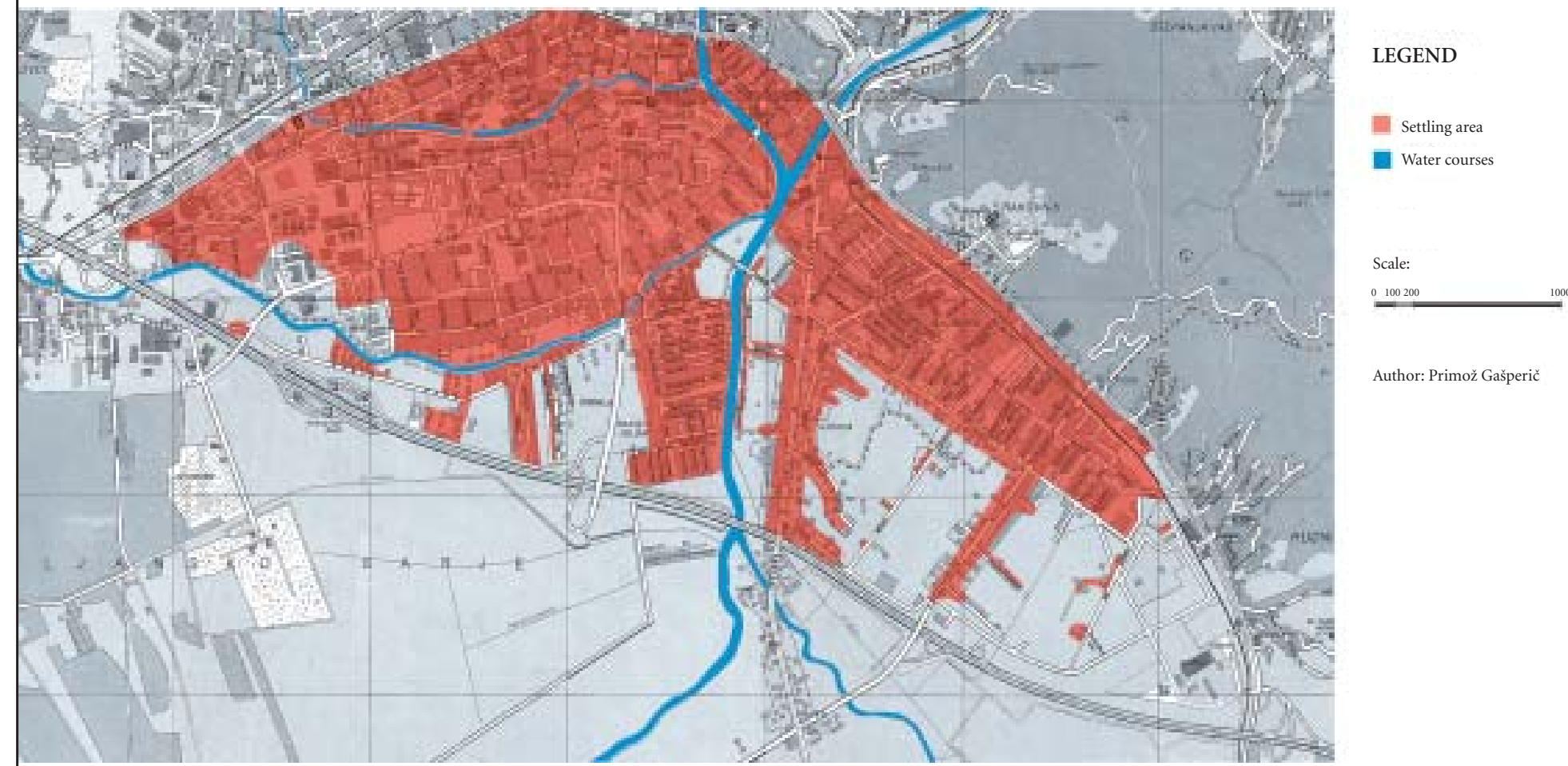

Author: Primož Gašperič 
Map 5: Expansion of the southern margins of Ljubljana, 1994.

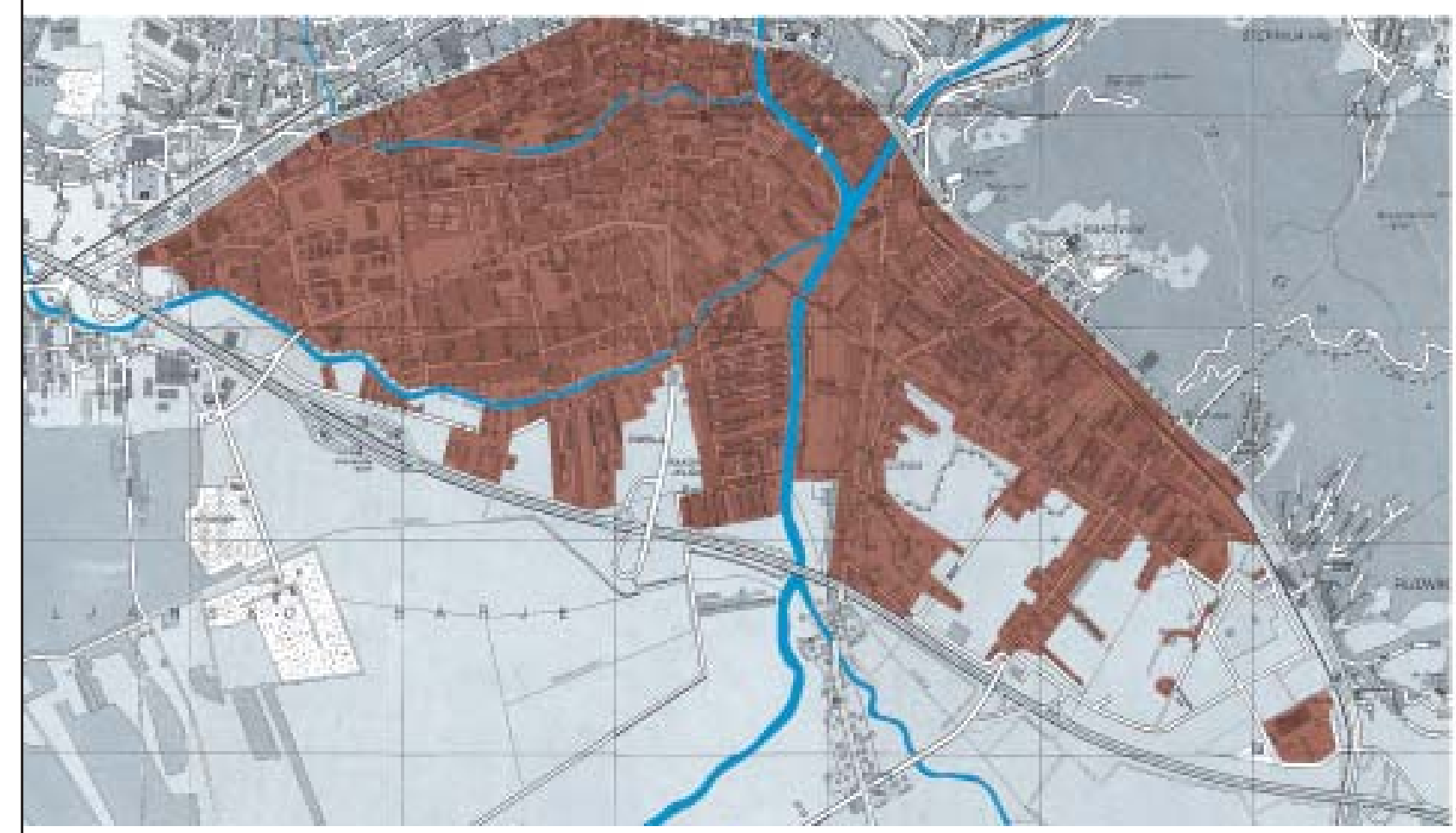

LEGEND

Eettling area

E Water courses

Scale:

0. 100200

Author: Primož Gašperič 


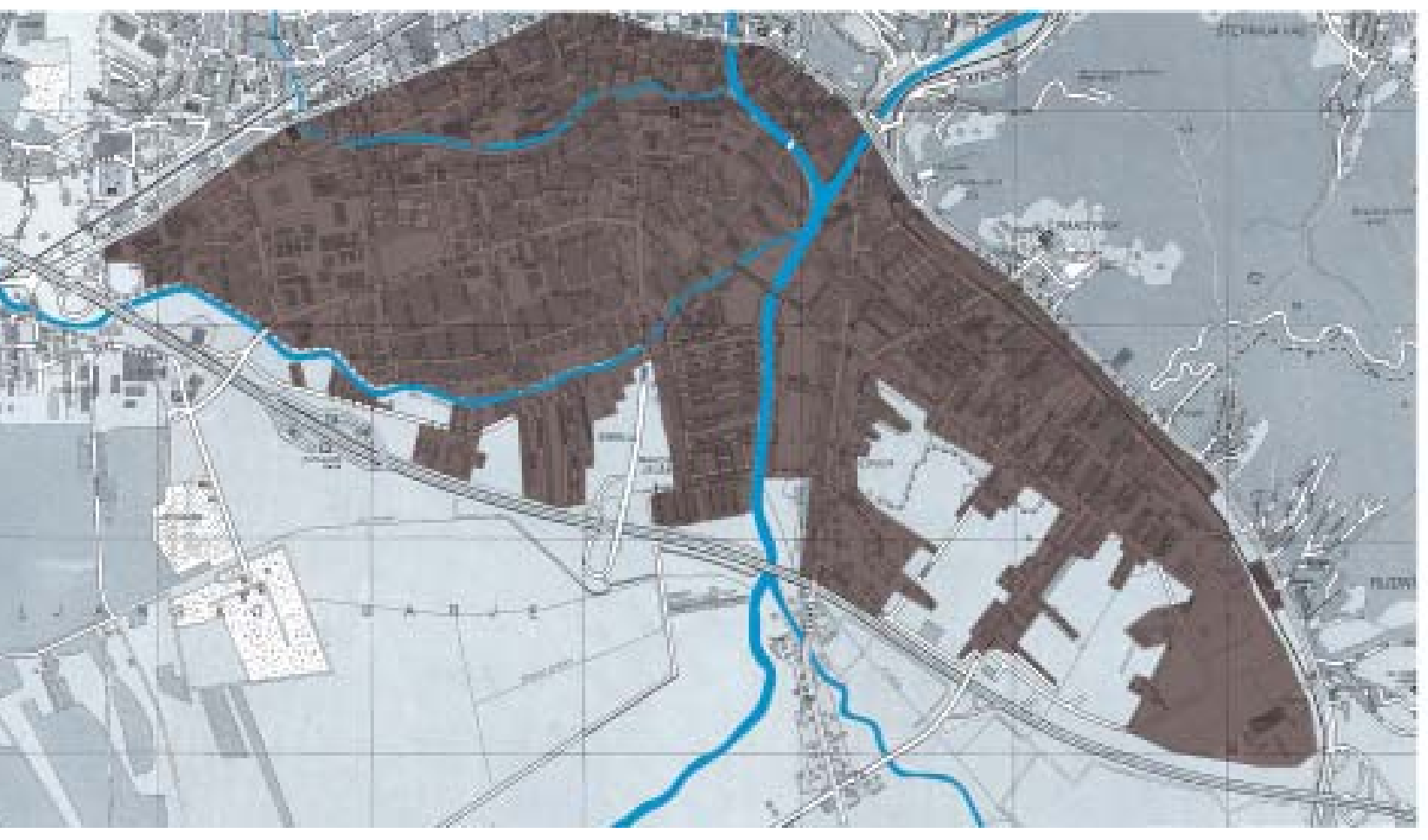

Settling area

Water courses

Scale:

0100200 
Map 7: Expansion of the southern margins of Ljubljana in the period between 1951 and 2002.

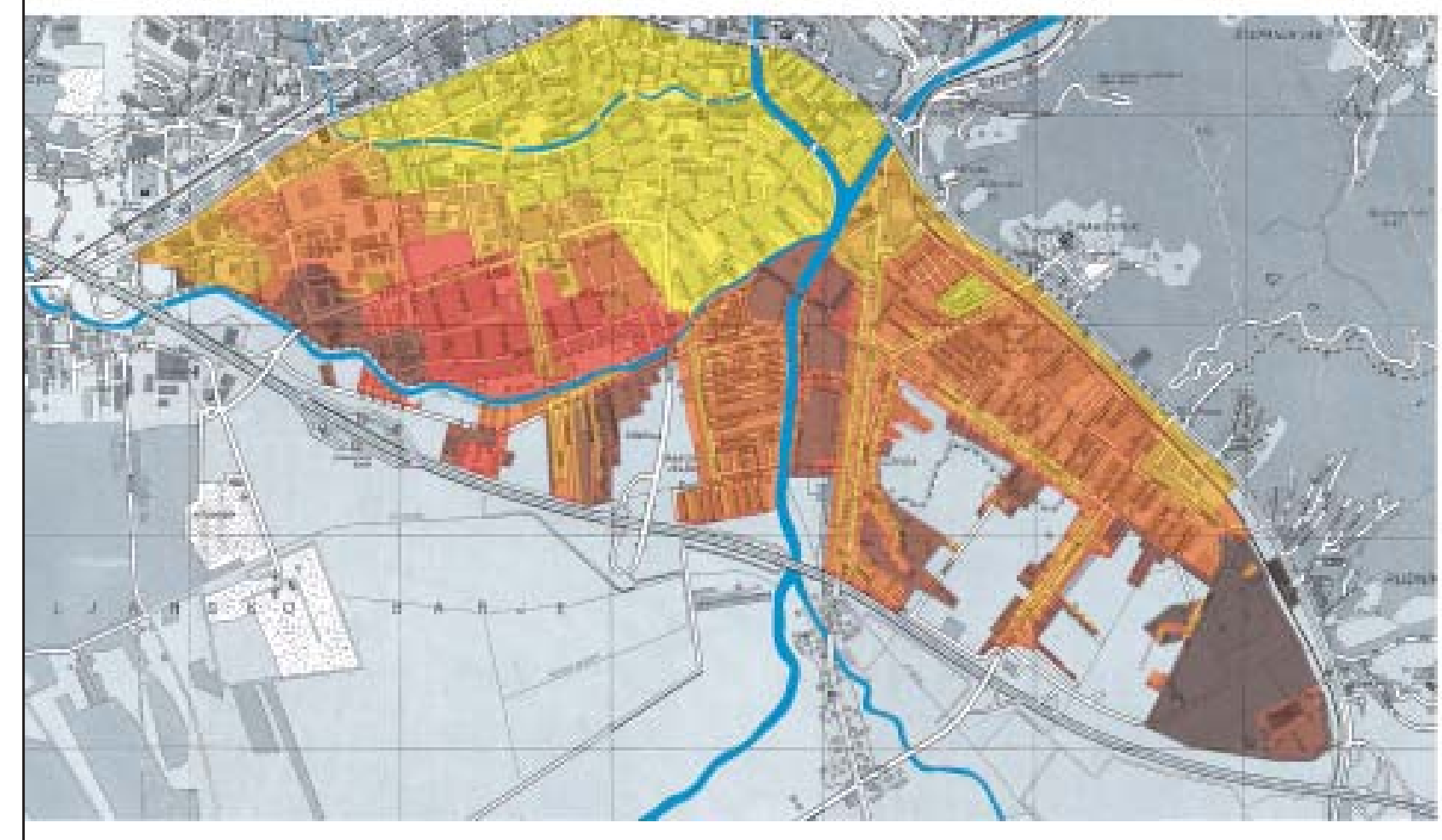

\section{LEGEND}

14 Year 1951

IIt Year 1964

III Year 1974

III Year 1982

E Year 1994

Year 2002

Water courses

Scale:

0.100200

Author: Primož Gašperič 
In the 1980's, the entire studied area became more densely settled, with the concept of neighbourhoods appearing in places (e.g., the Trnovo apartment block complex) while individual construction continued elsewhere. Due to the general social situation in the country, gradual changes occurred in the field of organized construction that dominated during the 1990's following independence and the introduction of democracy. A more market-oriented approach to the construction of apartments appeared that changed the orientation of construction toward providing higher levels of comfort and attractiveness.

At the end of the 1980's, the southern Ljubljana ring road was completed and played an important role in the studied area for several reasons. Along with indirectly marking the border of the expansion of Ljubljana, it had a very important impact on the traffic flow to and from the studied area. Later city planning and the distribution of service activities are related to this factor. The studied area was no longer a marginal place serving only for residences but became an intermediate space between the city and the surrounding area. Suited to circumstances, the area began to develop further in the 1990's. We can see from Figure 6 that the situation did not change substantially in the eastern part of the studied area, which was originally settled with individual houses and the construction of row houses (Livada). In the western part, however, the expansion of the city continued even further southward to reach the Mali graben stream south of Murgle, leaving only an area of undeveloped land between the upper end of Cesta v Mestni log and the more southern stretch of the Mali graben stream. South of the Mali graben stream, settling became denser and expanded along Cesta dveh cesarjev, where the development of two »islands« of settling showed the potential for merging into a single entity.

Toward the end of the 1980's and in the 1990's, there were major changes in the organization of apartment construction. The initiative for investment and the construction of apartment blocks and other buildings was taken over by construction companies that were oriented toward market-oriented construction and the sale of real estate. This resulted in greater concern for the quality of apartments and residential buildings and the living environment. Apartment construction became more attuned to the demands of the market, and the construction of above-standard apartments began that surpassed the previous norms for individual apartments relative to their size and furnishings. Furthermore, due to market demand, at the end of the 1990's the organized construction of single-family row houses and atrium houses revived (for example, in Galjevica), restarting or gradually continuing with the construction of larger residential neighbourhoods such as the Galjevica-Karlovško suburb (Rebernik 1999b, 38).

The consolidation of the settling area (in the smaller southern part of Murgle immediately beside the Mali graben stream, the final buildings in the development of one-story single-family houses were completed) and individual minor expansions of the studied area southward, mostly in the eastern part, mark the period after 2000. The exception is the easternmost part of the studied area, where major changes have occurred in the last three years. Recently, this somewhat distant area, which was not considered an urban part of Ljubljana because of its barrenness, was transformed into a shopping center of great size within a very short time. This shopping center, which is still in the development phase, concludes the expansion of the city toward the southeast.

\section{Conclusion}

The process of urbanization was influenced by natural conditions and the later intensity of expansion onto the Ljubljansko Barje moor. Within this urbanization, we can trace individual suburbanization processes that are the consequence of the rapid settling trends in the urban area.

If we ignore the first decade of the studied period when city planning was not yet oriented toward the moor, we can see that since then the process of urbanization has been very much alive and dominant. At the moment, we are witnessing the final phase, which has already outlined the final shape of future spatial development. The process of suburbanization has not yet encompassed the studied area, but processes within the urbanization have begun to occur that are typical of suburbanization. The special feature of the studied area relative to the urbanization process is the late start of settling in the area, whose north- 
ern part bordering the city center was previously considered something of a suburb while in the south it was a typical moorland farming area. However, after World War II with the growth of industry and the consequent immigration of workers and their families to Ljubljana, the expansion of the city southward onto the moor was inevitable. Due to its late settling and its proximity to the city center, the process of urbanization was extraordinarily intensive. In only a few decades, the area was transformed into a completely built-up urban area. The city expanded, but particularly in the area east of the Ljubljana River, not densely enough, so the process is still continuing there. In the western part of the studied area, the greater part of the area is already urbanized, a process assisted by the early planned and illegal construction that occurred here. Because of the empty land that is still found at good locations relative to its proximity to the city center, many residents of the city decided to move. This could be seen as the suburbanization of an area very close to the center of the city and simultaneously as the continuing urbanization of the wider city area.

In spite of many open questions, we can conclude that the urbanization of the studied area is well advanced. With the settling of still unoccupied areas, which continues taking place in individual parts, the expansion period is in its concluding phase. Although initially the significance of its proximity to the city center went unrecognized, the studied area is too attractive and therefore too important a part of Ljubljana as a whole not to continue the already active process of qualitative transformation. With the rapid growth of commercial activity, the planned construction of comfortable houses and apartments, the gradual improvement of the infrastructure network, and the planned renovation and further construction of the sewage system, the studied area is becoming a modern urban environment that will above all serve to satisfy the needs of its residents.

\section{Bibliography}

Bregar, F. 1996: Pokrajinsko-ekološko vrednotenje Ljubljane in okolice z vidika širjenja urbanizacije. Diplomsko delo, Filozofska fakulteta. Ljubljana.

Cunder, T. 1984: Ogroženost Ljubljanskega barja po poplavah in potresih s posebnim ozirom na južni rob Ljubljane. Diplomsko delo, Filozofska fakulteta. Ljubljana.

Gams, I., Cunder, T. 1983: Ljudska zaznava ogroženosti ter znanje o potresih in poplavah: na primeru južnega roba Ljubljanskega barja. Naravne nesreče v Sloveniji. Ljubljana.

Gašperič, P., Kertel, R. 1965: Demografski učinki urbanizacijskih vplivov v občini Ljubljana Vič-Rudnik. Diplomsko delo, Filozofska fakulteta. Ljubljana.

Kolbezen, M. 1984: Hidrografske značilnosti poplav na Ljubljanskem barju. Geografski zbornik 24. Ljubljana.

Lah, A. 1963: Problemi urejevanja in gospodarskega izkoriščanja Ljubljanskega barja v obdobju 1945-1961. Doktorska disertacija, Filozofska fakulteta. Ljubljana.

Ljubljansko geografsko društvo. 2000: Ljubljana - geografija mesta. Ljubljana.

Lovrenčak, F., Orožen Adamič, M. 1999: Ljubljansko barje. Slovenija, pokrajine in ljudje. Ljubljana.

Mihelič, B. 1983: Urbanistični razvoj Ljubljane. Ljubljana.

Mlinar, M. 1987: Suburbanizacija v Ljubljanski regiji. Geografski obzornik 34. Ljubljana.

Mestna občina Ljubljana. 2001: Prostorski plan Mestne občine Ljubljana. Prostorska zasnova: gradivo za razpravo. Ljubljana.

Orožen Adamič, M. 1984: Prebivalstvo, poselitev in promet na Ljubljanskem barju. Geografski zbornik 24. Ljubljana

Ravbar, M. 1994: Spremljanje in vrednotenje suburbanizacijskih procesov. Kvaliteta življenja in kvaliteta bivalnega okolja Ljubljane, 1. faza. Ljubljana.

Rebernik, D. 1999a: Prebivalstveni razvoj Ljubljane po letu 1945. Geografski vestnik 71. Ljubljana.

Rebernik, D. 1999b: Socialna geografija Ljubljane. Doktorska disertacija, Filozofska fakulteta. Ljubljana.

Rus, A., Stanič, I. 1993: Členitev mesta Ljubljana. Geografski vestnik 66. Ljubljana.

Vrišer, I. 1956: Razvoj prebivalstva na območju Ljubljane. Knjižica Kronike, časopisa za slovensko krajevno zgodovino 2. Ljubljana. 


\section{Uvod}

Pričujoči članek želi prikazati širitev mesta Ljubljana in postopen premik njegove južne meje na Ljubljansko barje. lzhajal sem iz dejstva, da se je Ljubljana zelo pozno začela širiti proti jugu, torej na barje, kljub temu pa je vrh največje urbanizacije že dosežen. Predpostavil sem, da proces poselitve še ni zaključen, vendar pa so začrtane že vse glavne smeri in da je večji del območja že poseljen. Obravnavano območje je najbolj južni del mesta Ljubljana. Do nedavnega se je na tem območju raztezalo predmestje, ki se je v zadnjih nekaj desetletjih zlilo z mestom kot nekakšen nov, dodaten in svojstven del celotnega mesta.

Teritorij je izbrano območje, ki sem ga prvotno omejil na podlagi mojih družbenogeografskih predstav. Smiselno se mi je zdelo zajeti celoten južni del mesta, s čimer bi v celoti ponazoril urbanizacijski proces širitve proti barju. Pri določanju južnega roba preučevanega območja sem se odločil za južno ljubljansko obvoznico, ki je nekakšen fizični mejnik prvotno sicer enotnega ozemlja. Kasneje se je izkazalo, da se območje deli na številne svojstvene urbane dele, ki pa kljub temu tvorijo skupaj celotno ozemlje »barjanske Ljubljane«, katere poselitvena meja je prav omenjena obvoznica.

Obravnavano območje je v nekakšnem trikotniku: na zahodu do Tržaške ceste z vzporedno železnico, na vzhodu do Dolenjske ceste z železnico in na jugu do že omenjene južne ljubljanske obvoznice. Meja na severu ni določena, ker se je mesto s severa širilo proti jugu.

Zajema približno $10 \mathrm{~km}^{2}$ površine in tvori le majhen del (približno 1/20) celotnega barjanskega ozemlja. Do druge polovice devetdesetih let je bilo to območje upravno razdeljeno na enajst krajevnih skupnosti: Barje, Galjevica, Kolezija, Milan Česnik, Stane Sever, Zeleni Log, Murgle, Peruzzi, Rakova Jelša, Trnovo in Rudnik. Pred nekaj leti so bile krajevne skupnosti ukinjene, območje pa se po novem deli na četrtne skupnosti: Rudnik, Trnovo in Vič. Te upravne razdelitve ne sovpadajo povsem s preučevanim območjem, vendar pa so odstopanja majhna.

Območje lahko označimo kot robno, prehodno in prepletajoče. Zaradi svoje lege in položaja, ki ga ima glede na mesto, je obravnavano območje robno. Tvori južni del mesta, ki se je le postopno urbaniziralo in se mu šele v zadnjih desetletjih priključilo. Zelo reprezentativna bi bila oznaka prehodno območje. Na severnem delu, ležečem najbolj proti mestu, gre za pravo podobo mesta, z vsemi njegovimi lastnostmi. Tukaj gre za veliko pozidanih površin, stanovanjskih naselij, storitvenih dejavnosti in malo obdelovalne zemlje ter rekreacijskih površin. Proti jugu in jugovzhodu se ta značaj mesta izgublja, zlasti manjša je gostota pozidanosti, vse bolj proti obrobju mesta pa se povečuje zlasti delež zelenih površin, ki zaradi opuščanja kmetovanja in nekvalitetne zemlje nimajo posebnega pomena in tvorijo kot veliki travniki vse bolj značilno barjansko podobo. V tej smeri se gostota poselitve znatno znižuje, vendar pa zelo močno upade oziroma je skoraj ni več (izjema so območja okoli večjih cest: Cesta dveh cesarjev, Ižanska cesta) šele južno od južnega dela ljubljanske obvoznice. Kljub temu da je bila obvoznica zgrajena sorazmerno pozno glede na širitev mesta, predstavlja mejo med relativno gosto poseljenim območjem in zelo redko poseljenim barjem.

Prav zaradi velikih razlik v rabi prostora, načinu poselitve in razporeditvi različnih vrst dejavnosti lahko trdimo, da je obravnavano območje nekakšen konglomerat mestnih, obmestnih in tudi vaških lastnosti. Vse se prepletajo znotraj relativno majhnega prostora. Vzrok za prepletenost pa poleg navedenega najdemo tudi v časovnem razvoju območja, saj je v postopnem spreminjanju od srede devetnajstega stoletja do srede dvajsetega stoletja, zelo intenzivno pa v zadnjih desetletjih, iz izrazito obmestnega in agrarnega območja nastal urbaniziran del mesta, ki ima posamezne še nepozidane »otoke« z značilnimi barjanskimi travniki.

\section{Oris obravnavanega območja}

Obravnavano območje je sestavni del mesta Ljubljane in geografsko gledano tvori južni del mesta. Vendar pa ni bilo od nekdaj tako. V preteklosti je bilo to območje sprva povsem izven mestnega območja. V času rimske vladavine je najjužnejši del mesta Emone segal na najbolj severni del obravnavanega območja, to je Mirje. To je še danes vidno, saj so ravno južni del emonskega obzidja in južna vrata še vedno ohra- 
njena in delno prenovljena. Še dolga stoletja po tem je ostalo to območje skoraj neposeljeno, saj zaradi nezaščitenosti pred naravnimi nesrečami (na primer poplavami) in nekvalitetne zemlje ni bilo privlačno za poselitev. Prve korenitejše spremembe v okolju so pogojevale tudi postopno poselitev tega dela barja. $\mathrm{V}$ drugi polovici 18. stoletja so se začela prizadevanja za osušitev barja in s tem resnejši posegi v ta prostor. Med leti 1772 in 1780 je bil izkopan Gruberjev prekop, ki je veliko prispeval k večjemu odtoku vode $\mathrm{z}$ barja in s tem zmanjšanju možnosti poplav. Poleg tega pa so postopoma izkopavali številne jarke tako ob cestah kot tudi med zemljišči.

Sčasoma so se začela oblikovati številna naselja, ki pa razen bližine Ljubljane niso imela veliko skupnega $\mathrm{z}$ njo. Tvorila so samostojne naselbinske enote, ki niso bile del mesta, vendar pa je kljub temu obstajala ekonomska povezanost, saj so $\mathrm{v}$ barjanskih naseljih blizu Ljubljane pridelovali zelenjavo in jo prodajali v mestu. Vodna pot (zlasti po Ljubljanici) je služila za povezavo tudi oddaljenejših krajev z mestom, saj so po njej prevažali poleg živil tudi potreben gradbeni material, npr. podpeški kamen, les.

V drugi polovici 19. stoletja, zlasti pa v 20. stoletju se je struktura rabe prostora in gostota poselitve bistveno spremenila. $\mathrm{Na}$ eni strani so uspehi z izsuševanjem tal in izgradnja posameznih prometnic, ki so povezovale te odmaknjene kraje z Ljubljano, omogočali večjo zgostitev prebivalstva v teh naseljih. Na drugi strani pa se je širila Ljubljana proti barju, ki pa je bilo v primerjavi z ostalimi smermi širitve med zadnjimi. Vzrok za pozno urbanizacijo južnega dela sedanjega obsega mesta lahko najdemo prav v strukturi barjanskih tal, ki niso bila ne dobro rodovitna ne primerna za vse vrste gradnje.

Do začetka 20. stoletja se je južni rob Ljubljane delil na tako imenovana predmestja. Na južnem delu mesta pod Gradom je bilo Karlovško predmestje, na drugi strani Ljubljanice pa Krakovsko in Trnovsko predmestje. Meje mesta Ljubljane so segale na jug do Malega grabna in do poti v Murgle, kjer sta še danes ohranjeni dve stavbi, ki sta služili kot nekdanji mestni mitnici. Ob Tržaški cesti sta bili manjši stari in agrarni naselji Glince in Vič.

Osrednji položaj na obravnavanem območju imata gledano geografsko in z vidika pokrajinske spremenljivosti Krakovo in Trnovo. Krakovo kot najsevernejši del obravnavanega območja, Trnovo pa kot nekakšen južni podaljšek mesta na barje. Trnovo je zanimivo še zaradi sorazmerno majhne površine, na kateri so se že v preteklosti, zlasti pa danes kazali na eni strani elementi pravega mesta, na drugi strani pa tipično barjanske, agrarne ostaline, ki nam priča o nekdanji drugačnosti prostora.

Mreža cestnih in železniških poti je bila prilagojene naravnim dejavnikom. Izjema pa je prav gotovo Ižanska cesta, zgrajena leta 1826, ki je predstavljala pomembno povezavo Ljubljane in Iga, s tem pa jugovzhodni del barja z mestom.

Kot edino daljše cestišče, ki ima zanimivo zgodovino nastanka in ki se skoraj v celoti nahaja na obravnavanem območju, naj izpostavim Cesto dveh cesarjev. Zgrajena je bila leta 1821, ko je v Ljubljani zasedal kongres Svete alianse. Avstrijski cesar Karel je peljal ruskega carja po prav za to priložnost zgrajeni cesti in mu želel pokazati najnovejše dosežke in ideje, s katerimi bi barje spremenili v žitnico.

Glavni cestišči, ob katerih potekata tudi edini železniški povezavi in ki hkrati tudi omejujeta obravnavani prostor in sta nekakšen »družbeni mejnik « med barjanskimi in nebarjanskimi tlemi, sta Dolenjska cesta in Tržaška cesta. Obe sta imeli svojo povezovalno vlogo že zelo zgodaj, smer, s katero sta Ljubljano povezovali, pa izražata že njuni imeni. Sta hkrati tudi v nekakšnem vzročno-posledičnem odnosu z Ljubljano, saj predstavljata glavni prometni žili mesta v smeri proti jugovzhodu in zahodu.

Najpomembnejša cestna pridobitev celotnega glavnega mesta pa je južni del ljubljanske obvoznice, ki je bil odprt konec osemdesetih let. Ob otvoritvi je predstavljal začetek gradnje cestnega obroča okoli vse številčnejšega glavnega mesta. Je tudi južna meja območja, ki ga zajema diplomsko delo (Gašperič).

Kljub sedanjemu neizkoriščanju vodnih tokov za prevoz materiala in ljudi je potrebno omeniti reko Ljubljanico. Že v rimski dobi so njeno strugo regulirali in jo zravnali, da je bilo možno neovirano pluti po njej. 
Vse do devetnajstega stoletja je predstavljala pomembno plovno pot, saj je bila ena izmed najdaljših in najpomembnejših plovnih poti na slovenskem teritoriju. Z razvojem cestne in železniške infrastrukture se je njen pomen nezadržno zmanjševal, danes pa predstavlja le športno in občasno turistično dejavnost.

\section{Možnosti poplav in potresov}

Ena največjih značilnosti in hkrati velika nadloga Ljubljanskega barja so poplave. Pogoste poplave zajamejo osrednje dele, kjer voda prekrije približno $15 \%$ celotne površine. Ob izjemno velikih poplavah je pod vodo kar dobra polovica Ljubljanskega barja. Od Vrhnike proti Ljubljani se poplavni svet oži. Številni vodotoki, zlasti Gradaščica, so na to območje nanesli veliko rečnih nanosov. Te nanose je reka nanosila iz severnih robnih delov, posledica pa je, da je površje zato višje in ga običajna poplavna voda ne zalije več. Zaradi umetnih in naravnih ovir se poplavni svet deli na več manjših delov. Meja pogostih poplav je zaradi dvignjenih bregov ob sami Ljubljanici odmaknjena od reke, ponekod tudi do 500 metrov. Ob izjemnih poplavah zalije voda velike površine južnih delov Ljubljanskega barja, na levi strani reke lahko sega vse do Trnovega. Povodnji na Ljubljanskem barju so najpogostejše jeseni in pozimi, malo poplav je poleti, nekaj več pa spomladi. Takšna razporeditev kaže na to, da so poplave v močni povezavi z razporeditvijo in količino padavin, ki padejo in ki po vodotokih odtečejo. (Lovrenčak in Orožen Adamič 1999, 383)

Vzroki za nastanek poplav so različni. Med najpomembnejše in prevladujoče uvrščamo tri bistvene vzroke:

- nekraške površinsko tekoče vode, zlasti Gradaščica in Iška, ob velikih padavinah hitro narastejo, poplavijo in zajezijo Ljubljanico ter dvignejo njeno gladino. Ko ta poplavna voda upada, začne pritekati visoka voda iz kraških izvirov, ki se je zadržala v kraškem podzemlju. Poplava iz kraških voda doseže višek kasneje kot površinske vode. Ta poplavna voda tudi kasneje upade, saj se voda v kraškem podzemlju počasneje pretaka,

- zelo velik pomen ima malo nagnjeno površje. Večina ljubljanskega barja je v višini med 288 in 289 metri. Na ravnem površju z manjšimi vzpetinami in kotanjami se poplavna voda zadrži še po tem, ko voda z vzpetin že odteče,

- med vzroki za nastanek poplav je tudi talna voda v vršajih na obrobnih delih Ljubljanskega barja oziroma $\mathrm{v}$ prodnih nanosih med posameznimi vodotoki. Ko talna voda doseže neprepustno ilovico na dnu barja, se pojavijo številni izviri. (Lovrenčak in Orožen Adamič 1999, 383 in 384).

Zelo razširjeno mnenje je, da so poplave sestavni del Ljubljanskega barja, vendar pa da niso reprezentativni naravni dejavnik za južni del mesta. Vsekakor je pogostost poplav na tem območju dosti nižja, saj so bila tekom minulega stoletja narejena, sicer bolj lokalno, regulacijska dela na posameznih vodotokih in številni jarki za odtekanje vode. Vendar pa v primeru spleta okoliščin, do katerih je prišlo na primer leta 1926 in 1933, ne bi bilo možno preprečiti ponovne katastrofalne poplave. Po pogovoru z nekaterimi poznavalci hidrografskih razmer in po obisku Vodnogospodarskega inštituta v Ljubljani se je izkazalo, da bi za preprečevanje poplav na obravnavanem območju morali zgraditi zbiralnike vode na posameznih vodotokih (zlasti na vodotoku Gradaščica), s čimer bi lahko nadzorovali vodostaj v primeru večjih količin vode, regulirali posamezne struge in s smotrnejšo pozidavo omogočili boljši odtok vode v kanale.

Z vse večjo časovno oddaljenostjo od zadnjih večjih poplav v dvajsetih in tridesetih letih minulega stoletja se tudi zavest in vedenje o poplavni ogroženosti zmanjšuje. K temu še dodatno prispeva močna urbanizacija z naselitvijo novih priseljencev $\mathrm{v}$ zadnjih desetletjih, ki ne poznajo naravnih procesov in razmer na barju. Na terenu se to odraža pri načinu poselitve in gradnje hiš. Veliko objektov ni dovolj dvignjenih od osnovnega nivoja tal in bi morebitna povodenj poplavila prostore v pritličju. Poleg načina gradnje in nekaterih izjav prebivalcev je anketa (Gams in Cunder 1983, 131 in 134), ki je bila izvedena že leta 1983, potrdila te domneve. Namen ankete je bil ugotoviti, kaj prebivalci menijo in vedo o potresih in poplavah na obravnavanem območju. Območje, ki ga anketa zajema, skoraj sovpada z obravnavanim območjem.

Del ankete je vseboval vprašanja o poplavah in vprašanja v povezavi z njimi:

- slabih 60 \% vprašanih ima tla stanovanja nižja od 20 centimetrov nad neposredno okolico,

- $72 \%$ ve, da je na njihovem območju možna katastrofalna poplava, 
- $59 \%$ jih ne ve, da je to območje že zajela poplava, $13 \%$ pa o tem nima svojega mnenja,

- $52 \%$ jih računa na to, da bi lahko prišlo do poplave,

- $53 \%$ domov je voda že kdaj zalila greznico,

- $25 \%$ ni vedelo odgovora.

Obravnavano območje poleg poplavne nevarnosti ogrožajo tudi potresi. Zaradi številnih prelomov in postopnega ugrezanja tal je na južnem delu Ljubljane potresna nevarnost z močjo nad deveto stopnjo po Merkalijevi lestvici. Vprašanje, ki se zastavlja, je, ali barjanska tla zmanjšujejo oziroma povečujejo potresno aktivnost. Z umetnimi simulacijami potresa so ugotovili, da barjanska podlaga še poveča stopnjo potresne aktivnosti in da na tem območju doseže tudi deseto stopnjo po Merkalijevilestvici. Ti podatki so zelo zaskrbljujoči, vendar pa je zavest o potresni ogroženosti majhna. Vsekakor je vzrok za to relativna redkost katastrofalnih potresov in že več kot sto let, odkar je zadnji prizadel Ljubljano. Ker so za območje značilne številne črne gradnje, se predvideva, da veliko objektov ni grajenih po zahtevanih merilih za protipotresno varnost. Po vsej verjetnosti je nepoznavanje terena in ekonomski status prebivalcev glavni razlog takšnega načina gradnje.

Zaradi potresne ogroženosti obravnavanega območja je drugi del ankete vseboval vprašanja tudi o tej problematiki:

- $43 \%$ vprašanih je bilo pred gradnjo seznanjenih z možnostjo potresa,

- 65 \% jih meni da se ne bi odločili za drug kraj bivanja, čeprav bi takrat imeli možnost izbire (verjetno je vzrok za to bližina mestnega središča),

- $39 \%$ jih je odgovorilo, da hiša pred potresom ni varna,

- $38 \%$ jih kdaj pomisli na možnost katastrofalnega potresa, $21 \%$ pa nikoli.

Ugotovitve, ki jih lahko povzamemo na podlagi rezultatov ankete, bi lahko na kratko povzeli tako: prebivalci obravnavanega ozemlja niso dovolj informirani in osveščeni o možnostih naravnih nesreč. Mnogi niso upoštevali možnosti teh nesreč že pri gradnji in je zato težko oceniti, do kakšne škode in morebitnih žrtev bi prišlo. Vendar pa so številni prebivalci izrazili pripravljenost sodelovanja s finančnimi sredstvi in delom pri morebitni skupni obnovi njihovih domov, s katero bi dosegli varnejše bivanje.

V zadnjih dvajsetih letih, torej v obdobju po izvedbi te ankete, lahko predpostavim, da se zavest o naravnih nesrečah ni povečala; upal bi si trditi, da se je celo zmanjšala. V prid tej predpostavki kažejo naslednji razlogi:

- osveščanje ljudi preko medijev ali s pomočjo katerih drugih dejavnosti in prireditev je zanemarljivo,

- na obravnavano območje se je po letu 1983 priselilo veliko ljudi z različnih koncev in upravičeno lahko domnevamo, da velik del ne pozna obravnavane problematike,

- tudi v zadnjih dvajsetih letih ni prišlo do katere od naravnih nesreč in se s časovno oddaljenostjo vedenje in zavest še dodatno zmanjšujeta.

\section{4 Širitev mesta proti jugu}

V petdesetih in deloma še $\mathrm{v}$ šestdesetih letih dvajsetega stoletja, je bilo območje, z izjemo najbolj severnih delov in posameznih obcestnih predelov (ob Tržaški in Dolenjski cesti), še zelo redko poseljeno in $\mathrm{s}$ povsem agrarnim značajem. Postopna širitev mesta, ki se začne $\mathrm{v}$ šestdesetih letih, je posledica dveh vrst urbanizacije. $Z$ načrtovano urbanizacijo se postavi smernice za nadaljnjo poselitveno smer in širitev na barje. Eden prvih in najobsežnejših posegov je naselje Murgle, ki od srede šestedesetih let bistveno spremeni podobo južno od Ceste v Mestni Log. S stihijsko ali tako imenovano črno gradnjo pa se začne nenadzorovana razpršena urbanizacija, ki postopno dobiva vse večji obseg. Kot najznačilnejšo in kasneje tudi najgostejšo »črnograditeljsko četrt « lahko izpostavimo Rakovo Jelšo. Prvotno nizko število črnih gradenj se postopoma zgoščuje do te mere, da postanejo zelo močan dejavnik oblikovanja naselbinskega sistema na obravnavanem območju. Postopna legalizacija teh objektov v devetdesetih letih legalizira te nenačrtovane poselitvene smeri in jih vključi v nadaljnji razvoj širšega mesta. 
Težko je določiti, katera od obeh vrst urbanizacij se je začela prej, vsekakor pa sta imeli podobne vzroke za nastanek in povsem različno realizacijo v prostoru. Glavni vzroki širitve zazidalnega in s tem tudi poselitvenega območja so bili:

- bližina mesta oziroma središča Ljubljane,

- nizka cena zemljišča ali podedovana posest,

- slaba oziroma nenadzorovana politika gradnje stanovanjskih objektov,

- možnost relativno nizkega začetnega kapitala, ki je omogočal izgradnjo sprva zasilnega bivališča,

- možnost »komunskega« naselja - območja, ki so privabljala enako usmerjene sloje ljudi iz ekonomskih, nacionalnih ali drugih razlogov,

- možnost poljubnega načina gradnje vendar v obsegu zmožnosti barjanskih tal.

Kljub različnim načinom gradnje in vzrokom za poselitev lahko govorimo le o postopni urbanizaciji, v sklopu katere se kažejo tako zelo značilne lastnosti suburbanizacije. Tudi zato je obravnavano območje svojsko. Še v petdesetih letih se že tako redko prebivalstvo seli bolj proti mestu ali v mesto in gostota poselitve v bolj oddaljenih delih takrat še predmestja se bistveno ne zgoščuje. Predpostavimo lahko, da gre pri urbanizaciji na obravnavanem območju za stekanje prebivalstva na to območje iz vseh koncev in posledično pride do širitve mesta. Ljudje se selijo na barje iz zgoraj naštetih razlogov, prihajajo pa prvenstveno iz bolj oddaljenih krajev. V nekaj desetletjih se obravnavani prostor zgosti do te mere, da poselitev tudi fizično doseže meje mesta Ljubljane, ki so nastale pod vplivom naravnih razmer in antropogenega delovanja. Najbolj značilna je prav gotovo južna meja, ki jo neposredno določa južna ljubljanska obvoznica. Na posameznih delih se pozidano območje že v sedemdesetih, izraziteje pa v osemdesetih letih dotakne te meje. Vendar pa je predvsem v vzhodnem delu obravnavanega območja še precejšen del tal nepozidan. Od devetdesetih let se tudi uradno poseljuje zlasti vzhodni del (vzhodno od reke Ljubljanice), črne gradnje pa so postopno legalizirane. Na to območje se več ne priseljujejo prvenstveno samo ljudje iz bolj oddaljenih krajev, ampak je veliko priseljencev iz bližnje okolice mesta ali pa Ljubljančanov. Slednji se odločajo za nakup vrstnih hiš ali individualno gradnjo zaradi pomanjkanja bivalnega prostora $\mathrm{v}$ mestu in/ali zaradi večje finančne zmožnosti. Ker so se ti prebivalci Ljubljane preselili na to območje iz mesta, torej je šlo za selitev iz mesta v mesto, ne moremo govoriti o suburbanizaciji. Poleg njih se na to območje še vedno selijo ljudje iz bolj ali manj oddaljenih krajev okoli Ljubljane in s tem spodbujajo še nadaljnji proces urbanizacije.

Postopoma se že pozidano območje zgošča tako po številu stavb kot po številu prebivalstva, saj so nekateri priseljenci tukaj že tri ali štiri desetletja in del mlajše generacije še živi pri svojih starših oziroma bodo predvidoma tam tudi ostali. S širitvijo urbaniziranega območja pa postopoma nastaja vse več storitvenih dejavnosti, ki se ukvarjajo predvsem s trgovino in številnimi vrstami obrti. Prvotno so bile te dejavnosti namenjene zadovoljevanju lokalnih potreb, v zadnjem desetletju, predvsem pa v zadnjih letih, pa so se razvili zelo veliki trgovski centri, ki so grajeni z namenom zadovoljevanja potreb širokega območja mesta in njegove širše okolice. S tem so bile postavljene trgovske kapacitete, ki bodo zadovoljevale zahteve bodočega zgoščenega poselitvenega območja. Tako se proces urbanizacije stopnjuje in postopoma napoveduje svoj konec, ki pa še ni tako blizu, saj bo potrebno še vsaj desetletje, preden bo poseljeno celotno območje. Glede na prostorske načrte, ki so predstavljeni v Prostorskem planu mesta Ljubljana, in po pogovoru z nekaterimi arhitekti posamezna manjša območja ne bodo pozidana, temveč bodo kot večnamenski prostor vključena $\mathrm{v}$ ta urbanizirani prostor. Tukaj gre predvsem za rekreacijske površine in površine, namenjene kasnejši namenski uporabi (na primer površina za mestno železnico).

Ljubljana je skozi svojo zgodovino dobivala središčno vlogo na ozemlju današnje Slovenije in nujna posledica je bila postopna širitev mestnega prostora. Vendar pa njena širitev ni bila enakomerna, za kar gre zasluga nekaterim fizičnim dejavnikom oziroma prostorski raznolikosti. Na vzhodu in zahodu sta bila to Tivoli in Grad, proti jugu pa Ljubljansko barje. Že Rimljani so poznali značilnosti barjanskih tal in so Emono zgradili na meji z barjem, vendar nekoliko severneje, kjer so tla trdnejša. Zanimivo je, da se je ta meja strnjenega naselja tekom stoletij premaknila le za kakšnih sto metrov proti jugu in le s posameznimi poselitvami vzdolž pomembnejših poti se je naselitev razširila na barje. $V$ devetnajstem in prvi polovici dvajsetega stoletja je ruralno predmestje segalo že povsem na barje, vendar o širitvi mesta proti barju še ne moremo govoriti, ker so to poselitev predstavljala manjša naselja z značilno ruralno funkcijo in poselitvijo (Trnovo, Krakovo) ter nekateri naselitveni otoki, ki so nastali zaradi reševanja posledic prve svetovne vojne (Galje- 
vica, Sibirija). Z rečnim prevozništvom in opekarskimi obrati, ki so delovali na južnem delu Trnovega (Opekarska cesta), se je naselitev utrdila, vendar pa niso bili dovolj močan dejavnik za zlitje z mestom.

Pozna širitev mesta na barje ni slučajna in je posledica številnih lastnosti in s temi povezanih problemov, ki so značilni samo za barjanska tla. Poglavitni razlogi, ki so negativno vplivali na možnost poselitve, so bili sledeči:

- zahtevnejša, zato lahko tudi dražja gradnja na pilotih oziroma nasipih,

- nerodovitna barjanska zemlja,

- visoka talna voda,

- možnost poplav.

S postopnim dvigom življenjske ravni so se zahteve ljudi po bivalnem udobju povečale in nekatere sestavine sodobnega bivalnega okolja (kanalizacijsko in infrastrukturno omrežje, prostoren in urejen bivalni prostor itd.) so postale nujne. Zato se je v obdobju po drugi svetovni vojni poleg zgoraj naštetih razlogov za kasnejšo poselitev barja pojavilo še nekaj novih zahtev, ki so botrovale poselitvi v naslednjih desetletjih in so še vedno pomemben dejavnik odločanja bodočih prebivalcev:

- dostopna cena parcele,

- napeljava infrastrukturnega omrežja,

- možnost priključitve na kanalizacijsko omrežje,

- bližina storitvenih dejavnosti,

- image okolja.

Našteti dejavniki so lahko negativni ali pozitivni - odvisno od posamezne lokacije znotraj obravnavanega območja. Npr. Rakova Jelša ima pri kanalizaciji in imagu bolj negativen predznak, pri ceni parcele pa bolj pozitiven predznak. V Murglah pa je ravno obratno.

Da se stopnja civilizacije spreminja in z njo zahteve po načinu življenja, je lepo vidno pri dejavnikih odločanja ljudi za naselitev oziroma gradnjo svojega doma. Na obravnavanem območju so bili pred in v začetku obravnavanega obdobja zgoraj našteti razlogi za neposeljenost, $\mathrm{v}$ šestdesetih in delno sedemdesetih letih dvajsetega stoletja so bili značilni odklonilni dejavniki naslednji: slaba napeljava infrastrukturnega in kanalizacijskega omrežja, malo storitvenih dejavnosti in s tem povezan slab image okolja. $\mathrm{V}$ osemdesetih in devetdesetih letih, še posebej pa prav v zadnjih nekaj letih so se zaradi postopne urbanizacije okolja razmere močno spremenile. Zaradi bližine centra mesta je obravnavani prostor postal zelo privlačna lokacija za naselitev in postavitev številnih dejavnosti. Zato je prišlo do razvoja infrastrukturnega omrežja in dviga kvalitete bivanja. Glavni omejitveni dejavnik poselitve pa je postala cena zemljišča in stanovanjskih objektov, ki je v primerjavi s prejšnjimi desetletji dosegla več desetkratno rast. Zato se v zadnjem obdobju na območja organiziranih ali samostojnih novih gradenj praviloma priseljujejo ljudje z dobrimi ali zelo dobrimi dohodki. Vendar pa je kljub temu struktura prebivalstva zelo heterogena, saj je večji del ljudi prišel na to območje še $\mathrm{v}$ času, ko nakup in gradnja nista bila tako draga.

Obravnavano območje je nekakšen konglomerat najrazličnejših slojev ljudi, različnih vrst naselij in dejavnosti. Prebivalci se izrazito razlikujejo po materialnem statusu in po kraju, od koder so se odselili na obravnavani prostor. Zato je prišlo ponekod do namenskega (Murgle), ponekod pa do spontanega nastanka posameznih območij (Rakova Jelša), ki vsaj na zunaj delujejo homogeno, kar lahko razberemo po načinu gradnje in strukturi prebivalstva.

Karta 1: Stanje pozidave južnega roba Ljubljane, 1951.

Glej angleški del prispevka.

Pregled širitve Ljubljane na barje se začne z letom 1951. To je obdobje, ko se razmere po drugi svetovni vojni postopoma umirijo, ko nastopi nova politična usmeritev in ponazarja še zadnje obdobje, ko na južnem robu Ljubljane še ni prišlo do širitve mesta in urbanizacija še ni posegla na to območje.

Meja mesta se $\mathrm{v}$ tem obdobju ne ujema $\mathrm{z}$ mejo poselitve, vendar močno izstopa delno strnjena poselitev proti jugu le v Trnovem in delno na Koleziji. Realna meja mesta poteka po Ljubljanici, od Spice do izliva 
Gradaščice in delno po Gradaščici. Trnovo in Krakovo sta že v predvojnem obdobju tvorila svojstven in zaokrožen prostor, kjer so prebivalci živeli prvenstveno od pridelave vrtnin za zalaganje mesta s svežo zelenjavo in od prevozništva po Ljubljanici. Dodaten razvoj so omogočali manjši obrati opekarn. Zaradi razvoja cestne infrastrukture in nekonkurenčnosti splavarjenje, čolnarjenje in opekarne propadejo, značilni vrtovi pa so v tem obdobju še prevladujoč način rabe tal. Skozi vsa obravnavana obdobja se vrtovi postopoma krčijo, vendar so se posamezne »krpe« ohranile do danes.

Karta 2: Stanje pozidave južnega roba Ljubljane, 1964.

Glej angleški del prispevka.

Za obdobje šestdesetih let je značilen začetek širitve mesta na barje. Širitev ni bila hitra in intenzivna, ampak postopna in večplastna. Na eni strani so začeli z gradnjo načrtovanih naselij, na drugi pa se na obravnavanem območju začne stihijska gradnja, ki v tem obdobju že delno pokaže nove smeri bodočega poselitvenega zgoščevanja.

Karta 3: Stanje pozidave južnega roba Ljubljane, 1974.

Glej angleški del prispevka.

Sedemdeseta leta so obdobje intenzivnega načrtovanega in stihijskega poseljevanja obravnavanega območja in s tem širjenja Ljubljane proti jugu. Murgle dobivajo svojo podobo naselja vrstnih enodružinskih hiš, ki ga tretja faza gradnje zaokroži, ne pa dokonča. V zelo kratkem času se razširi poselitev v Rakovi Jelši in dobi meje poselitve, ki veljajo še danes. Južno od Dolenjske ceste se z intenzivno gradnjo vrstnih in individualnih hiš meja poselitve premakne do Jurčkove ceste. Glede na prejšnjo obdobje se močno okrepi ta vrsta gradnje in dobi prav v sedemdesetih letih najbolj intenzivno obliko, vzroki za to pa so bili, kot že rečeno, ekonomski.

Karta 4: Stanje pozidave južnega roba Ljubljane, 1982.

Glej angleški del prispevka.

V osemdesetih letih se celotno obravnavano območje zgoščuje, ponekod se oblikuje koncept stanovanjskih sosesk (trnovski bloki), drugod pa nadaljuje individualna gradnja. Zaradi splošnega družbenega stanja $\mathrm{v}$ državi prihaja postopno do sprememb na področju načina organizirane gradnje, ki v devetdesetih letih, po osamosvojitveni vojni in z uvedbo demokracije, prevlada. Gre za bolj tržen način namenske stanovanjske gradnje, ki spremeni način gradnje v smislu večje stopnje udobja.

Konec osemdesetih let je zgrajena južna ljubljanska obvoznica, ki je za obravnavani prostor pomembna iz več razlogov. Poleg tega da posredno nakaže mejo širitve Ljubljane, zelo pomembno vpliva na prometno povezanost obravnavanega območja. $S$ tem dejavnikom pa so povezani bodoči urbanistični načrti in razporeditev storitvenih dejavnosti. Obravnavano območje ni več nekakšen obrobni prostor, ki bi služil zgolj poselitvi, temveč postane vmesni prostor med mestom in okolico. Temu primerno pa se območje začne razvijati v devetdesetih letih. Iz karte št. 6 lahko razberemo, da se na vzhodnem delu obravnavanega območja poselitveno stanje ni bistveno spremenilo: območje se je prvenstveno zgoščevalo $\mathrm{z}$ individualno gradnjo in gradnjo vrstnih hiš (Livada). Na zahodnem delu pa je širitev mesta napredovala še bolj proti jugu in južno od Murgel dosegla Mali graben, le med zgornjim koncem Ceste v Mestni log in južneje tekočim Malim grabnom je ostal del nepozidane površine. Južno od Malega grabna pa se zgošča in širi poselitev ob Cesti dveh cesarjev, kjer je z nastankom še dveh poselitvenih »otokov« nakazana možna nadaljnja gradnja v povezano celoto.

Karta 5: Stanje pozidave južnega roba Ljubljane, 1994.

Glej angleški del prispevka.

Proti koncu osemdesetih let in v devetdesetih pride v organizirani stanovanjski gradnji do velikih sprememb. Pobudo za gradnjo in investiranje stanovanjskih in drugih objektov prevzamejo gradbena podjetja, ki so usmerjena v tržno gradnjo in prodajo nepremičnin. To vpliva na večjo skrb za kvaliteto stanovanja in stanovanjskih zgradb ter bivalnega okolja. Stanovanjska gradnja se bolj prilagodi tržnemu povpraševanju. Začnejo se graditi nadstandardna stanovanja, ki po svoji velikosti in opremljenosti pre- 
segajo dotedanji normativ za posamezno stanovanje. Poleg tega se zaradi tržnega povpraševanja ponovno okrepi organizirana gradnja enodružinskih vrstnih in atrijskih hiš (na primer Galjevica), ki se ob koncu devetdesetih let ponovno začne oziroma postopoma nadaljuje z gradnjo večjih stanovanjskih sosesk (na primer: Galjevica - Karlovško predmestje) (Rebernik 1999b, 38).

Karta 6: Stanje pozidave južnega roba Ljubljane, 2002.

Glej angleški del prispevka.

Za obdobje po letu 2000 je značilno zgoščevanje poselitvenega območja (na manjšem južnem delu Murgel, tik ob Malem grabnu, gradijo še zadnje hiše v sklopu pritličnih enodružinskih hiš) in posamezna manjša širitev obravnavanega območja proti jugu predvsem na vzhodnem delu. Izjema je skrajni vhodni del obravnavanega območja, kjer je $\mathrm{v}$ zadnjih treh letih prišlo do zelo velikih sprememb. Nedavno še zelo odmaknjeni del, ki zaradi neobljudenosti ni bil štet kot urbani del Ljubljane, je postal v zelo kratkem času trgovski center velikih razsežnosti. S tem trgovskim centrom, ki je še v fazi razvoja, je zaključena širitev mesta proti jugovzhodu.

Karta 7: Stanje pozidave južnega roba Ljubljane po obdobjih 1951-2002.

Glej angleški del prispevka.

\section{Sklep}

Proces urbanizacije je bil pogojen z naravnimi pogoji in kasnejšo intenziteto širitve na barje. Znotraj urbanizacije pa lahko zasledimo posamezne suburbanizacijske procese, ki so posledica hitre poselitvene tendence tako rekoč mestnega območja.

Če odmislimo prvo desetletje obravnavanega obdobja, ko se mestni urbanizem še ne usmeri na jug proti barju, lahko ugotovimo, da je proces urbanizacije od takrat še zelo živ in prevladujoč. Trenutno smo priče zadnji fazi, ki je že nakazala dokončno obliko bodočega prostorskega razvoja. Proces suburbanizacije še ni zajel obravnavanega območja, prihaja pa do procesov znotraj urbanizacije, ki so značilni za suburbanizacijo. Posebnost obravnavanega območja v sklopu urbanizacijskih procesov se skriva v poznem začetku poseljevanja tega prostora, ki je bil v severnem delu, kjer je mejil na center mesta, tretiran kot primestje, proti jugu pa se je nahajalo tipično barjansko agrarno območje. Vendar pa je po drugi svetovni vojni z razmahom industrije in posledično priseljevanjem ljudi v Ljubljano prišlo do nujne širitve mesta tudi na barje. Zaradi pozne poselitve in majhne oddaljenosti od centra, je bil proces urbanizacije toliko bolj intenziven. $\mathrm{V}$ samo nekaj desetletjih se je prostor spremenil v povsem pozidano mestno območje. Mesto se je razširilo in zlasti na območju vzhodno od reke Ljubljanice še ne dovolj zgostilo, zato se ta proces odvija še sedaj. Na zahodnem delu obravnavanega območja se je urbaniziral že večji del ozemlja, k temu pa je pripomogla zgodnja načrtovana in stihijska pozidava. Zaradi omenjenega praznega prostora, ki je še vedno na dobri lokaciji glede na oddaljenost od središča mesta, so se mnogi prebivalci mesta odločili za preselitev. Temu bi lahko rekli suburbanizacija ožjega središča mesta in nadaljnja urbanizacija širšega mesta.

Kljub mnogim odprtim vprašanjem lahko zaključimo, da se je oblikovanje mesta na obravnavanem območju šele dobro začelo. S poselitvijo še neposeljenih območij, ki na posameznih delih še poteka, se zaključuje širitveno obdobje. Zaradi prvotno ne dovolj prepoznavnega pomena bližine središču mesta je obravnavani prostor preveč atraktiven in s tem pomemben del celotne Ljubljane, da se ne bi nadaljeval že začeti proces kvalitativnega preoblikovanja. Z močno rastočo trgovsko dejavnostjo, načrtovano gradnjo udobnih hiš in stanovanj, postopnim izboljševanjem infrastrukturnega omrežja in načrtovanjem gradnje ter prenove kanalizacijskega omrežja se obravnavano območje spreminja v sodobno urbano okolje, ki bo prvenstveno služilo zadovoljevanju potreb njenih prebivalcev.

\section{Literatura}

Glej angleški del prispevka. 